\title{
Pussy Provocations: Feminist Protest and Anti-Feminist Resurgence in Russia
}

\author{
Jessica Mason ${ }^{1 *}$
}

Published: March 19, 2018

\begin{abstract}
The Russian feminist punk-art group Pussy Riot sparked a remarkable series of responses with their provocative "punk prayer" in a Moscow cathedral in 2012. This article analyzes the social, political, and cultural dynamics of provocation (provokatsiya) by examining everyday conversations, speeches, articles and other linguistic acts through which Russian Orthodox, feminist, and left-leaning and liberal participants in the anti-Putin opposition made sense of Pussy Riot. A provocation violates norms in ways that compel observers to name and defend those norms. This process simultaneously invigorates norms and helps people shore up their own senses of self amid uncertainty. Yet what observers identify as the provocation - what norms are perceived to be violated — shapes what values they reinforce. Responding to Pussy Riot, Russian Orthodox activists asserted themselves as defenders of tradition against the forces of Western cultural imperialism, including feminism and LGBT rights. Yet most responses from the anti-Putin opposition focused on norms related to speech and protest rights, while Russian feminists were often reluctant even to claim Pussy Riot as feminist at all. Due to this asymmetry, Pussy Riot's feminist protest revitalized antifeminism in Russia without a concomitant strengthening of feminist values among supporters.
\end{abstract}

Keywords: Russia, feminist politics, right-wing politic

\section{INTRODUCTION}

We consider the "punk prayer" an extremist crime, degrading millions of women of faith, and demand an appropriate legal assessment be given by society and those in power to this action. It is necessary to denounce this provocation, so that such antics are not repeated. Otherwise, our society can safely be characterised as terminally morally ill.

In March 2012 the Union of Orthodox Women, a Russian civil society organisation, released this statement in response to a performance almost nobody witnessed: the 'punk prayer' of the self-described 'feminist punk-art group' Pussy Riot. Five figures in bright dresses, anonymous under colourful balaclavas, had momentarily taken over the altar of the Cathedral of Christ the Savior (CCS) in central Moscow, shouting a punk song whose lyrics attacked the intimate church-state alliance that increasingly limited women's and LGBT rights in Russia: "Mother of God, chase Putin out! Mother of God, become a feminist!" It lasted only about two minutes before the performers were escorted out by security. Combining video footage of this performance with material recorded elsewhere and including their tussle with the Cathedral guards, the Pussy Riot collective uploaded a finished video to YouTube on February 21. By March 4, two members of the group, Nadezhda Tolokonnikova and Maria Alyokhina, had been arrested. They were soon joined by a third, Ekaterina Samutsevich. The video, along with news of the jailed women, continued circulating online ${ }^{1}$. With its rough, hand-made costumes, lyrics more shouted than sung, and a clear, even crude, feminist message, the group's performance evoked the 'Riot Grrrl' feminist punk rock movement that developed in the 1990s United States, remade for a 21 st-century media landscape ${ }^{2}$.

The Union of Orthodox Women deemed Pussy Riot's performance a "blasphemous act [that] insulted not only the feelings of the faithful, but also the heroism of our ancestors." Strong words for a song, particularly for one

\footnotetext{
1 As of May 2017, the video and accompanying post about the action remains available at: http://pussyriot.livejournal.com/12442.html

${ }^{2}$ For a discussion of comparisons between Pussy Riot and Riot Grrrl, see Groeneveld 2015.
} 
that circulated mainly online and whose punk aesthetic had little resonance for the average Russian Orthodox believer. That an organisation created by the Russian Orthodox Church and with close connections to the ruling party — its leadership included members of the Russian Duma ${ }^{3}$ — would level such words against a half-dozen artists who were relatively unknown outside art and activist circles seemed inexplicable. How could such a marginal group provoke such a strong backlash?

Over the year and a half following the punk prayer, I was conducting fieldwork on gender politics in Moscow amid a wave of mass protests against Russian President Vladimir Putin, primarily with feminist, LGBT, and leftist opposition activists who were working to persuade participants in the broader opposition movement to support feminist and pro-LGBT themes. Their goals included ending harassment of women and LGBT activists within the movement, adding stronger social programs such as better child care to the opposition's platform, and uniting against the Putin government's attacks on LGBT Russians. Even as the three arrested members of Pussy Riot disappeared into the Russian criminal justice system, the theme of Pussy Riot was nearly inescapable. My social media feeds - in Russian and in the English-language — flooded with debates about Pussy Riot. Opposition rallies and marches were filled with signs, chants, and even balloons referring to the group. Pussy Riot — an action, an idea, an iconic image - circulated through public events and everyday conversations, in mass media and online, in Russia and abroad. The case prompted a highly publicised court trial, prison sentences for two members, a new law to make offending religious sentiments a criminal offence ${ }^{4}$, as well as sundry conference papers, books, documentary films, and even a concert featuring pop icons like Madonna and Blondie.

A growing body of feminist, social science, and area studies scholarship has shown how Pussy Riot's punk prayer and its aftermath illuminated key tensions that animated Russian politics and activism in 2012, in particular the repressive power of the Putin-era state, the influence of conservative Russian Orthodoxy and its relationship with state nationalism, and the central roles of gender and spectacles of gendered violence in the Putin government's consolidation of authoritarian power (Bernstein, 2013; Johnson, 2014; Rourke and Wiget, 2016; Schroeder and Karpov, 2013; Shevzov, 2014; Sperling, 2015; Tolstaya, 2014). Scholars have also examined what the Pussy Riot case reveals about new forms of feminist protest in Russia (Johnson, 2014) and globally (Baer, 2016) and how local feminist organising is transformed through transnational solidarity efforts and the circulation of prominent cases like that of Pussy Riot (Channell, 2014; Groeneveld, 2014; Wiedlack and Neufeld, 2014). These studies have underscored the remarkable ability of the Pussy Riot case to clarify key values in Russian and Western societies that are contested in contemporary politics. While previous studies have generally focused on what meanings people have ascribed to Pussy Riot and their punk prayer, this article examines how and why people made the Pussy Riot case meaningful.

Analysing how politically engaged feminists, participants in the anti-Putin opposition movement, and Russian Orthodox women interpreted and responded to the Pussy Riot case, I define and describe a phenomenon that may be central to contemporary reactionary politics: provocation (Russian provokatsiya). A provocation is a type of action that violates a norm in ways that seemingly compels one to respond, from the perspective of the person who has been provoked. In the Union of Orthodox Women's statement, for example, the punk prayer's offence to women of faith is so extreme that it is 'necessary' to denounce it, lest society itself be further degraded. This feeling of compulsion is central to the subjective experience of provocation: provocation seems to be an attack on one's worldview, one's values, and even one's own sense of agency: one seems to have no choice about whether to react. Crucially, provocation induces a sense of acute need to articulate the norms being transgressed, and at the same time functions as an opportunity to defend those norms, meaning that provocation has the potential to reinvigorate the very norms and values it is felt to challenge. As I show below, through their reactions to the provocations they identified in the Pussy Riot case, my interlocutors positioned themselves within an ever-shifting political field and asserted their own normative visions of how the world ought to be.

My analysis of the Pussy Riot cases focuses on the everyday conversations, speeches, articles and other linguistic acts through which the politically engaged Muscovites I worked with expressed and circulated ideas about Pussy Riot. I examine why Pussy Riot seemed to have a magnetic pull on conversation and what kinds of social and cultural work all that talk was doing. This analysis of Pussy Riot aims to explain provocation and how it can make certain political actions particularly resonant, eventful, and even 'viral' - which might seem like a boon to grassroots feminist activists like the members of Pussy Riot. Yet, as I show, the dynamics of provocation can limit a protest's ability to effect change, instead serving as a spur to reinforce the very norms that activists are challenging or to draw attention to entirely different values than the original activists intended. While this article focuses on

\footnotetext{
${ }^{3}$ For example, its advisory board includes Yelena Mizulina, head of the Russian Duma Committee on Family, Women, and Children's Affairs. Mizulina is known for her leading role in passing legislation to criminalize so-called 'gay propaganda' and to decriminalize domestic violence, among other issues.

${ }^{4}$ Federal Law of the Russian Federation No. 136-FZ On Amendments to Article 148 of the Criminal Code of the Russian Federation and Certain Legislative Acts of the Russian Federation to Counter Insult of Religious Beliefs and Feelings of the Citizens, Ros. Gaz., No. 6117, Jul. 2, 2013.
} 
the implications of this process of crystallisation for feminist activism, a clearer understanding of the dynamics of provocation may help illuminate a variety of cases in which responses to a protest shift away from the protester's original intent. For example, in 2017 whilst American football player Colin Kaepernick began kneeling during the U.S. national anthem to protest police brutality, opponents claimed his provocation violated values of patriotism, leading some of his defenders to focus on asserting their own patriotism in response. It is this dynamic of provocation that the present article addresses.

I collected conversations about Pussy Riot from March 2012 through to May 2013 amongst the politically active people I was working with, finding that three groups of interlocutors emerged based on how they responded to the Pussy Riot case: conservative religious activists; opposition activists who were opposed to Putin but who did not primarily identify as feminists; and feminist-identified activists. When conservative religious activists talked about Pussy Riot, that talk enabled them to assert their own positions as defenders of tradition against the forces of Western cultural imperialism and materialist values. These observers often framed their responses explicitly in terms of opposing Western feminism and ideologies of sexual freedom. Yet most responses from anti-Putin opposition activists focused on defending norms related to speech and protest rights vis-a-vis the state, often positioning the Pussy Riot defendants as particularly vulnerable as women - a set of responses that did little to defend the values of gender equality and LGBT rights the group explicitly emphasised in their performance. Meanwhile, other Russian feminists tended to position themselves as ambivalent toward Pussy Riot, focusing their interpretive energy on defining the boundaries of feminism and appropriate protest.

Furthermore, I argue that provocation is an important dynamic in reactionary conservatism, explaining how individuals who belong to a politically and culturally dominant group can experience their position as that of an embattled minority. In the case of Pussy Riot, the process of provocation illustrates how a feminist protest might energise an anti-feminist right wing movement without spurring a parallel resurgence of feminist mobilisation. Examining how and why "Pussy Riot" was circulated by these groups and others, I argue, shows the potential value and risks of provocation as a tactic for activists with few resources and marginalised causes. Provocation is a generative action, creating opportunities for challenging and renegotiating norms by unsettling them. At the same time, provocation can also induce a hardening of those same norms, producing continuity in how power is structured.

\section{THE PUNK PRAYER MOVES FROM CATHEDRAL TO STREET}

I first encountered Pussy Riot at a political rally in honour of International Women's Day on March 8, 2012, just a few days after the arrests. The Russian liberal-democratic party Yabloko had organised a rally in downtown Moscow along with local feminist, leftist ${ }^{5}$, and LGBT activists and organisations. The bitter cold numbed my toes as I joined other attendees filing through the police security check into the square around the Monument to the 1905 Revolution. The stoic faces of the doomed revolutionaries loomed above as the crowd grew. Activists, many of them Russians in their teens and twenties, passed out flyers, set up a sound system, and unfurled flags and posters: "Women make revolution, not soup!" and "For quality day care!" The crowd gradually grew to four or five dozen.

Suddenly, a cluster of people coalesced near the security gate. Voices rose. On tiptoe, I peered through the small thicket of cameras and microphones aimed at the scene. The police were trying to take an activist's poster for having an extremist slogan. The offensive message? "We don't need flowers when we're being arrested", a reference to the two Pussy Riot members who remained in jail and to the culturally conservative customs with which most Russians marked the holiday. Despite its origins in the $19^{\text {th }}$ century women's movement, since the mid-20th century International Women's Day in Russia has typically been celebrated by giving gifts of flowers and chocolates to the women in one's life with little mention of feminism or women's emancipation ${ }^{6}$. The poster thus simultaneously rejected conventional femininity — "We don't need flowers" — while defending troublemakers who were clearly on the wrong side of the Kremlin. The rally organisers insistently defended the poster, brandishing a city-approved permit to express women's rights themes at the rally. For once the police desisted, letting the activist go and giving her poster back. The poster was propped up defiantly against the revolutionary monument for the duration of the rally, linking the rally to the Pussy Riot case in a kind of solidarity.

\footnotetext{
${ }^{5}$ Here, 'leftist' indicates activism ideologically and socially linked to global 'New Left' anti-capitalist movements. The leftist activists I worked with considered their politics distinct from old-guard communist organisations with origins in the Soviet system, more Occupy Wall Street than Communist Party.

${ }^{6}$ This depoliticisation resembles the shifts in the meaning and celebration of Mother's Day in the United States, which originated in the women's anti-war movement but by the mid-20th century had become a celebration of conventional motherhood through gift-giving.
} 
Moments like this, in which someone referenced some aspect of the case, thereby circulating ideas about Pussy Riot, would punctuate protest rallies, public events, and everyday conversations around Moscow for months to follow. At first glance, this widespread circulation of Pussy Riot might appear to raise not only the group's profile, but also of what the group's members considered its feminist views. For example, the punk prayer's lyrics explicitly attacked the ways in which a close Church-state alliance threatened LGBT Russians' freedom and ridiculed the government's patriarchal, pronatalist policies:

Black robes brag, golden epaulettes

All parishioners crawl to bow

The phantom of freedom is in heaven

Gay Pride sent to Siberia in chains

The head of the KGB, their chief saint

Leads protesters to prison under escort

To be sure not to offend His Holiness

Women must stick to making love and babies $[\ldots]$

Mother of God, Virgin, become a feminist

Become a feminist, become a feminist (Pussy Riot, 2012)

The reactions provoked by Pussy Riot's protest show that their action was successful insofar as it drew national and even global attention. In the context of a country where mass media are increasingly controlled by the state, the simple fact that Pussy Riot's performance circulated among the public was noteworthy. As 'Olga,' a radical feminist and LGBT activist, wrote,

Pussy Riot chose punk-rock and illegal partisan ${ }^{7}$ performance because they were needed to express [the group's] position in conditions of bought-off and lie-ridden mass media, and likewise of conservatively oriented cultural institutions. They used a bright, postmodern, provocative uniform, which successfully contrasted itself with the formalised social consciousness. [...] The bright uniform, taken from oi!-punk, and above all, the provocativeness allowed them to attract the attention of various levels of society. And they started talking about Pussy Riot.

Olga was right: people talked about Pussy Riot. The provocations of the Pussy Riot case prompted people to talk about themselves, their own political predicaments, and certain kinds of values - but not necessarily the values related to feminism and LGBT rights that Pussy Riot's song lifted up.

The specific ways in which my interlocutors among Russian feminists, as well as in the broader anti-Putin opposition, felt compelled to respond to Pussy Riot tended to emphasise themes of civil rights and repressive state power, rather than the more pointedly feminist and LGBT themes raised in the group's song. Examining these responses through the concept of provocation illuminates how, despite mass circulation of and attention to the Pussy Riot case, these themes central to the group's song essentially fell to the wayside.

\section{MAKING SENSE OUT OF PUSSY RIOT: CLASPS AND EVENTFULNESS}

The Pussy Riot case seemed to surface constantly during my fieldwork, an unavoidable topic of conversation. Yet my interlocutors rarely discussed the works and views of the group in and of themselves. More often they focused on the form the group's actions took, what they thought of the group, and how other people responded to Pussy Riot's performances, particularly the punk prayer. Similar to the linguistic process Susan Gal describes as a 'clasp' (Gal, 2007), comments about Pussy Riot asserted links between the speaker, Pussy Riot, and other topics. Through this process of rhetorical connection, a speaker creates a relationship between herself and the subject of her speech, and simultaneously places them both within a broader social/moral/political landscape. For example, the sign at the International Women's Day rally linked the sign-maker to Pussy Riot — "We don't need flowers when we're being arrested" - and implicitly set both in opposition to patriarchal holiday rituals and a repressive state. It is this quotidian linguistic work that created the political landscape of Moscow I witnessed in 2012 and 2013. Yet the fact that my interlocutors could discuss Pussy Riot in this way does not explain why they seemed compelled to do so or why the Pussy Riot case demanded attention.

\footnotetext{
${ }^{7}$ Partizanskoe, a reference to guerrilla fighters such as the Soviet partisans who fought within German-occupied territory during World War II.
} 
To begin answering that question, I turn to processual or event-focused anthropology. Social events, from cockfights to initiation rituals, have long been of interest to anthropologists for what they revealed about cultural continuity and change, their "relation between a certain happening and a given symbolic system" (Sahlins, 1985: 153). Continuity was assumed to be a given, while what needed explanation were the variations, changes, and discontinuities (Robbins, 2003). This approach informs analyses of Pussy Riot that examine how the group's performance illustrated key themes in Russian gender and politics, the Pussy Riot-as-litmus-test approach. In a sense, it also informs the self-presentation of the Union of Orthodox Women, which interpreted Pussy Riot's punk prayer as 'a blasphemous act' - a rupture of norms - and presented its own members as defenders of "traditional values" - the very definition of continuity.

But this dichotomous approach risks taking for granted that such a thing as a 'given symbolic system' exists prior to and outside events, missing the ways in which social values and norms are constituted from moment to moment through social action, such as how people create and respond to an event. The need to avoid taking symbolic systems for granted may be especially acute in situations of conflict and profound uncertainty, such as war zones or periods of revolution. What could a 'given symbolic system' entail when an entire world has been shattered by war (Hoffman and Lubkemann, 2005; Das, 2007)? Similarly, across the former U.S.S.R. the dissolution of socialism and introduction of late- $20^{\text {th }}$ century neoliberal capitalism radically upset formerly stable systems of meaning, causing what has been characterised as a society-wide experience of liminality (Oushakine, 2004), or a dissolution of Soviet doxa combined with discursive destabilisation (Yurchak, 2006; Zavisca, 2011). In situations characterised by such uncertainty, it is not clear that an analytical distinction between continuity and change can even be made. The appearance of cultural continuity, such as the claim by politically active Russian Orthodox adherents that they are defending 'traditional' values, cannot be taken for granted because it is in fact "the product of effort," as Sally Falk Moore writes (1987: 727). Events are thus useful to analysts because they can make this process visible, providing "evidence of the ongoing dismantling of structures or of attempts to create new ones" (1987: 729).

I suggest that in such unsettled circumstances, the meaning-making power of events may be especially beguiling not only to analysts, but to the people trying to inhabit those liminal and uncertain worlds. As Hoffman and Lubkemann suggest, events have a "generative capacity" and "present themselves as moments of shifting possibility and constraint for the crafting of subjectivity" (2005: 324). Set within the shifting and confusing world of post-Soviet Russia, the Pussy Riot case was an event that invited a tremendous amount of meaning-making, rich in symbolism and occurring in a moment rife with eventful political action. From this perspective, the Pussy Riot case didn't merely crystallise key cultural themes or prompt changes in Russian politics and culture, but was an instrument for generating both. Furthermore, I argue, some events do more than merely present a moment of possibility for crafting selves and creating structures. When an event seems to transgress norms so radically as to threaten their destruction, it confronts an observer with a 'normative indeterminacy' so intolerable that the observer feels forced to make 'clasps', to engage in that process of interpretation and norm-asserting. Such an event transgresses the boundaries of the normative in a way that almost demands the observer articulate and reinvigorate the norm she feels to be threatened. This is, I argue, what the Union of Orthodox Women meant by 'provocation'.

\section{MEETING THE PROVOCATEUR}

I offer this term with the caveat that calling something a 'provocation' typically implies a normative judgment, delegitimising the alleged provocateur by implying that $\mathrm{s} /$ he is only interested in sparking a response or starting a fight. Nonetheless, having examined how the term was used by my Moscow interlocutors, I propose it here as analytically useful to describe how a particular type of politically meaningful event unfolds, contributing to a deeper understanding of confrontational forms of political activism like Pussy Riot's punk prayer, and how they are made to matter. Provocation transforms a Pussy Riot — or even with someone else's commentary on Pussy Riot from a mere object of conversation to an aggressive agent in the field of political action.

This sense of provocation was not only in use among Russian Orthodox activists. As my leftist interlocutors recounted and planned public events, the provocateur (provokator) was a common figure they referenced. For example, leading up to a Labour Day rally, one leftist group anonymously published instructions for members on a social media site. The author reminded readers that the purpose of their participation was to share certain carefully crafted messages with the public: the necessity of self-organisation of workers, a change in Russia's power structure, wariness of the liberals and media figures who named themselves leaders of the opposition movement. The article concluded with a warning:

Don't get into senseless clashes with the police. Unfortunately, the authorities are not yet on our side. Stop the provocateurs who are trying to start such clashes or to call for them. If these clashes start anyway, try to lead away attendees along with your friends and acquaintances to a safe place. If for some 
reason even that becomes impossible, and it becomes necessary to oppose police violence and mass arrests, organise for self-defense, join together, give aid to the injured and support to the arrested with actions of solidarity.

A provocateur might interrupt a political action and prevent activists from pursuing their own projects. Note that the provocateur's power opposes, or even undermines, the activists' own desires and plans; they are instructed to try to avoid being drawn into clashes, but warned that such clashes might happen anyway. The provocateur thus holds the potential power to shape the actions of others contrary to their own intentions.

'Provocation' may also be used as an explanation or excuse for otherwise egregious behaviour, as when the Moscow police claimed that they were forced to make mass arrests during a public protest due to "provocateurs" in the crowd, or when 'Ivan,' a socialist activist, offered this explanation of a "comrade" who attacked an LGBT activist at a protest march:

Unfortunately, right now many LGBT activists — and not just LGBT, by the way, but also anarchists, vegans, people who fight for animal rights, I don't know who else $[\ldots]$ - in relation to other groups, [conduct themselves] very aggressively. Unfortunately, despite the fact that, say, at the Social March the comrade from the Left Front was clearly not in the right when he tried to rip the flag away from the girl who was carrying a rainbow flag, all the same, she was also being provocative.

Yet even dismissive uses of 'provocation' still carry the same understanding that provocation is characterised by a sense that the provoked person no longer has agency and has been made to respond against their own will. In Ivan's telling, it was not right for his comrade to rip a rainbow flag away from a fellow protester at the Social March; however, his assertion that "she was also being provocative" implies that it was the girl with the rainbow flag who caused the problem. The kinds of reactions that ensued from Pussy Riot's punk prayer show that most observers experienced their action or other aspects of the case as provocations in this sense.

\section{ANTI-FEMINIST REVITALISATION: THE RUSSIAN ORTHODOX REACTION}

What, then, did my interlocutors identify as the norms transgressed by Pussy Riot's punk prayer and its aftermath? One can start with the group's name, which despite being English and essentially meaningless in Russian, was readily understood as something crude by most Russians I talked to, whether or not they knew the English slang term ${ }^{8}$. The group's performance likewise seemed perfectly designed to cause a stir, transgressive in form, content, and location, as many academic commentators have noted. All the known members of Pussy Riot were young women. Their performance was not simply a protest of citizens against powerful political institutions, but a protest by young feminist women against institutions dominated by powerful older men. The gendered aspect of the case shaped how it was circulated and what people found provocative about it. As Anya Bernstein describes, media coverage of Pussy Riot's trial focused intensely, even erotically, on the three women defendants' bodies, which she argues "became vital sites for the enactment of sovereignty for a wide range of citizens" for whom the young women of Pussy Riot served as a sacrifice to sovereign violence (Bernstein, 2013: 222). Furthermore, the performance itself included crude and politically pointed language, dancing, and the use of musical instruments at the altar of an Orthodox cathedral. Crucially, the specific site of the performance, CCS, is closely associated with the Putin-era government's cultivation of Russian Orthodoxy as something close to a state religion and its reclamation of pre-Soviet history as part of official national identity.

Certainly members of the Union of Orthodox Women viewed Pussy Riot's action as an extreme provocation, reading their action as particularly degrading to women. The organisation's statement in late March 2012 linked Pussy Riot to moral decay and threats to core values:

The recent outburst of a so-called punk group, which considers itself feminist, plunged the majority of citizens of Russia into shock. The blasphemous act insulted not only the feelings of the faithful, but also the heroism of our ancestors who died on the fields of battle in the Fatherland War of 1812.

We consider the 'punk prayer' an extremist crime, degrading millions of women of faith, and demand an appropriate legal assessment be given by society and those in power to this action. It is necessary to

\footnotetext{
${ }^{8}$ Most often, the group's name was written in Latin characters, and occasionally it was transliterated (Pussi Raiot), but in conversation the group was always referred to as Pussy Riot, not a translated phrase. One of my former Russian language instructors, a member of the intelligentsia in his $60 \mathrm{~s}$, refused to refer to the group by name any time we discussed them, explaining that he did not want to "continue their performance".
}

$6 / 14$

(C) 2018 by Author/s 
denounce this provocation, so that such antics are not repeated. Otherwise, our society can safely be characterised as terminally morally ill.

Provoked by Pussy Riot's punk prayer, the Union of Orthodox Women rhetorically established relationships between the group's action, their alleged allies and inspirations, and an imagined community of symbolically charged victims whose fundamental values were transgressed. First, they link the 'so-called punk group', Pussy Riot, to feminism. The two are then juxtaposed to the Union of Orthodox Women and "the majority of citizens of Russia," making clear that neither Pussy Riot nor feminists count as Russians, who have been 'plunged...into shock' by their provocations. Next, Pussy Riot's action is named 'blasphemous', not only un-Russian, but also counter to all that is sacred in Russian Orthodoxy and insulting to the ancestral war heroes to whom CCS was dedicated.

To understand the latter clasp, it is important to note that Pussy Riot's punk prayer was performed during the $200^{\text {th }}$ anniversary of Russia's victory over Napoleon; CCS had originally been built to commemorate this victory. Under Stalin, the cathedral had been demolished and replaced with a public swimming pool, then in the 1990s it was rebuilt in gold-leaf and marble glory, with some government assistance, as part of the return of Russian Orthodoxy to the public sphere. ${ }^{9}$ CCS's services for major Orthodox holidays are often televised and attended by prominent state officials. Throughout 2012, the Russian government and Orthodox Church collaborated on a series of commemorative events, including public and televised services at the recently rebuilt CCS and events such as the return to the cathedral of a sacred icon purported to have aided the defence of Moscow and Stalingrad against the Nazis. At the time of Pussy Riot's performance, CCS had been increasingly used to link the contemporary state to imperial history, the history of Orthodoxy, and the return of the Orthodox Church to public life after socialism - all values that this statement drew on, reinforcing an official narrative of historical and cultural continuity.

By prompting this process of naming and linking the communities and values under attack, provocations like the punk prayer can result in the clarification and revitalisation of the institutions and social norms they target. The Union of Orthodox Women's response asserted that Church, nation, and ancestors were not only all victims of the punk prayer, but that they were united in a shared community, the "majority of citizens" whose interest was the health of "our society." The statement constructed an entire moral world whose contours have been laid bare by the provocation of the punk prayer. The use of the term 'provocation' in this response helps illustrate the normrevitalising process of norm violation. The authors worry that this "blasphemous act" is not an outlier, but a hint of worse to come. Pussy Riot far exceeded the limits of acceptable behaviour and did so in a particularly publicly meaningful place. Such an action must be answered, lest it invite further blasphemies and the erasure of norms altogether.

One key feature of a provocation, then, is that it threatens the social order through transgression. As Anna Temkina and Elena Zdravomyslova (2012) point out, transgression of norms in a symbolically rich performance is a key reason why the group's performance attracted such attention. Simultaneously, though, provocation presents an opportunity to assert what the social order is by claiming that it has been transgressed. In an environment of uncertainty, where norms are unclear and unsettled, provocation carries the potential to redefine what kinds of actions are possible and permitted. The provocation causes observers to feel they must respond in order to constitute and defend their preferred social order. In this case, the combination of location, form, and message of Pussy Riot's action appeared acutely threatening to many Orthodox women whose political projects are directed toward increasing respect for Orthodoxy and the influence of the Orthodox Church in public life.

Presenting at a major conference in October 2012 for Russian Orthodox women active in social and political work, 'Anna,' a retired schoolteacher, invoked Pussy Riot as an example of what she perceived as declining morality all around:

We unfortunately in this year must talk about declines in morality, about declines in morals, about the demographic crisis, about the crisis in motherhood [...] Young women break into a cathedral, put on so-called "punk prayers." [...] That those who perpetuate the case of the movement Femen, as the movement is called by feminists, absolutely so to speak related to the feminist movement, are prepared to rip up holy crosses, and that is good to them. I would like to remind you again that the cross wasThe first cross worshipped in Russia was raised by Queen Olga. It's not that today young women just behave themselves that way and that this happens. I think this is not simply a sad event. It was made by our terrible time. It was an attack on Orthodoxy and an attack also on us.

\footnotetext{
${ }_{9}^{9}$ The Cathedral also receives about 350 million rubles/year from the Moscow city budget (2013). Soderzhanie khrama Khrista Spasitelia v 2013 godu oboidetsia biudzhetu Mosckvy v 350 mln rublei. Gazeta.
}

(C) 2018 by Author/s 
Anna's organisation had released a statement online shortly after Pussy Riot's action expressing a similar set of associations:

The main purpose of women - is it really causing boorish behavior, the satisfaction of vile passions, the desire for wealth? If this is really so, then it is a shame for all women. What kind of example will we leave for our descendants? What kind of families will they create?

The concept of "women's happiness" is deliberately distorted in the eyes of the public, encouraging women to relate disparagingly to traditional family values, placing in the forefront only the cult of consumption and social self-realisation.

Already now we see how actively feminist organisations support the idea of safe abortions, the LGBT community, sterilisation and other such things. Is this the defence of women's rights? Not one of them talks about chastity, about the right of a woman to give birth to a child, about fidelity and self-sacrifice.

Interestingly, Anna asserted a connection between Pussy Riot and the Ukrainian feminist group Femen, which had felled a large cross in a public action in Ukraine shortly after the sentencing of the three convicted Pussy Riot members. Femen was perhaps best known for actions featuring its young female activists appearing topless in public, often with messages written on their bodies highlighting issues such as sex trafficking. Anna establishes an opposition between Orthodoxy and feminists, a group which includes both Pussy Riot and Femen and which both signals and causes moral decline (see also Channell, 2014 and Zychowicz, 2011). At the same time, Anna allies herself and her audience with Orthodoxy, morality, and Russia. Her vilification of Pussy Riot and other "feminists" helps establish Anna's position as a defender of morality and the nation in a time of crisis.

As Anna's multifaceted clasp shows, the punk prayer was especially resonant because of its openness to further associations. A provoked observer could reach to a wide range of potential meanings to connect to the case and thereby a wide range of potential norms and values to reinvigorate. Yet that openness to clasps also meant that Pussy Riot's own goals and intentions exerted only a limited influence on the outcomes of their provocation. The highly contested questions of Pussy Riot's relationship to the anti-Putin opposition, and to feminism and other feminist groups, illustrates this symbolic openness. In particular, it illustrates how each observer's responses to the provocations of Pussy Riot enabled the action to reinvigorate the anti-feminist values described above, without having a parallel energising effect on values related to feminism and LGBT rights.

\section{STATE POWER, NOT FEMINISM: LEFT AND LIBERAL OPPOSITION REACTIONS}

The asymmetry in which values were reinvigorated resulted from how sympathetic observers identified the provocation of Pussy Riot: which aspects of the event they considered provocations, which norms they believed were being transgressed, and which values needed defence. Many people within the anti-Putin opposition identified the authorities' repressive response to Pussy Riot as the fundamental provocation of the case, linking the group to repression at large rather than to problems facing women or LGBT individuals in particular. As a result, their defences of the group had little to say about feminism. Instead, people active in the opposition tended to interpret the Pussy Riot case in ways that reinforced values related to state power, and even to reinforce patriarchal norms by centering several members' status as mothers.

The response of self-proclaimed opposition leader Aleksey Navalny is illustrative. A lawyer, Navalny came to prominence through blogging about government corruption and had a substantial following in anti-Putin circles, though the leftist, feminist, and LGBT activists I worked with were concerned about his lack of interest in labour rights and his tendency to lean on nationalist and xenophobic rhetoric. In a blog post shortly after the three Pussy Riot members were arrested, Navalny expressed a common liberal opposition response to the case:

The action of theirs in CCS - it was idiotic and there's no disputing that. [...]

I, to put it mildly, wouldn't have liked it if at the moment when I was in a church, some kind of crazy girls ran in and started to run around the altar.

We have an indisputable fact: fools who carried out some minor hooliganism for the sake of publicity. Now there are two main questions:

1. Have they committed lawbreaking of a character so dangerous to society, to hold girls behind bars?

Obviously - no.

2. Are there circumstances that preclude holding the defendants in custody?

Obviously — yes. 
Nadezhda Tolokonnikova has a small child. A four year old girl.

Maria Alyokhina has a son who is five years old.

There is no reason to hold them in detention. (Navalny, 2012)

As Bernstein (2013) describes, it was common for opposition members to raise the fact of Nadya's and Masha's motherhood as exacerbating what they saw as an oppressive state response to an 'idiotic' action. Not only did defences like Navalny's fail to link the group's action to feminist values, but they reinforced the rather anti-feminist notion that the women were more sympathetic and valuable as mothers than as political actors (see also Agaltsova 2014, Sperling 2014). Indeed, Navalny's interpretation refuses to attribute any political message at all to the group, instead simply calling them 'crazy girls'. Instead, Navalny focuses on the case as one more in a line of instances of unfair treatment of powerless citizens by a corrupt and powerful government, comparing the detention of Pussy Riot to recent criminal cases involving a bank official and a local government official, who received more lenient treatment for more serious offences.

"[The Pussy Riot members] have been locked up in a cell for 60 days during the investigation of an offense for which it's not possible to give more than a sentence of five days' arrest. [...] This is senseless and disgusting cruelty, much worse than their stupid, but minor hooliganism."

Even more sympathetic feminist responses often identified the state's punitive response as the primary provocation of the case. Olga gave me a copy of an essay she had written for a samizdat ${ }^{10}$ feminist literary journal when I asked her what she thought of the group. Olga had trained as a historian but had made a career in media amid the crises of the post-Soviet period; her insightful analyses of contemporary politics drew on this professional experience as well as her academic training. About Pussy Riot's resonance with the public, she had written:

They appeared in the needed time in the needed place and revealed those acute social problems which had long been brewing in society, but which nobody could quite so precisely poke a finger into. [...] It is entirely true that if the three members hadn't been arrested, Pussy Riot would have remained a punk feminist youth group, an art-activist project, which would have developed within the frame of the youth culture-protest political movement. But their arrest— that continuation of their performance, a growth of their performance in the mass scale of the entire country-that's what made Pussy Riot a phenomenon.

This emphasis on Pussy Riot as examples of the Russian state's abuse of civil rights meant that while Orthodox women shored up anti-feminist values in response to Pussy Riot, Russians active in the opposition instead reinforced a worldview opposed to state oppression that lacked a particularly feminist component. For example, at the March of Millions opposition protest in September 2012, hundreds of participants had signs, balloons, tshirts, and other materials echoing the group's multicoloured balaclavas. When I asked 'Dasha', a leftist activist in her late teens, why Pussy Riot was such a strong theme at this protest, she told me, "They're a symbol of repression now." Dasha explained that the Pussy Riot case demonstrated the excessive force being used by the authorities against protestors, including herself and many of her friends. She did not raise the issue of feminism or mention LGBT rights.

Echoing Dasha's linkage of Pussy Riot to other examples of state repression, many signs at the march mentioned the members of Pussy Riot alongside other opposition protesters who had been arrested on seemingly specious charges. While the Union of Orthodox Women viewed Pussy Riot as agents of a blasphemous feminism and pro-LGBT activism, these protesters viewed Pussy Riot's case as evidence of encroaching authoritarianism undermining norms of free political speech. In a way, it didn't matter what Pussy Riot's intended message had been: the fact that they had been imprisoned merely for singing in a cathedral was the provocation. This defence was powerful — but it did not bring feminism to the centre of the opposition movement in the way that Orthodox activists so tightly linked opposition to feminism with their defence of the Russian nation and the Orthodox Church.

One April evening as I walked with 'Alex' to his socialist organisation's weekly meeting, he asked me whether I found Pussy Riot's name offensive in English. I responded that it wasn't the sort of name I would mention to my grandmother, then asked what he thought of the group in general. Alex explained:

\footnotetext{
10 'Self-published', a term often used to refer to censored materials that were published by Soviet dissidents, and which contemporary activists occasionally use today. Indeed, their publishing practices have more than a little continuity with those of earlier dissidents. Igor's organization had acquired a large copy machine, which occupied a corner of their headquarters/office, and which they used to produce leaflets and sometimes journals like "No Means No!" They currently used a professional printer to produce large quantities of journals and their occasional newspaper, but in earlier periods they had had difficulty finding a printer willing to publish their materials.
} 
'Our official position is not to support such actions because they are not helpful. This is just actionism. It doesn't express any message, especially to the common people, to the workers. They don't understand an action like this. But of course we don't support the excessive repression used against the group.'

Drawing on his own experience as well as his study of Marxist theory, Alex positioned the punk prayer as the wrong kind of protest, not aligned with him or his comrades, but the state's prosecution of the group as also in opposition to his positions. In other words, he wasn't exactly on Pussy Riot's side with respect to provocative punk feminist acts, but he certainly wasn't on the state's, either. While maintaining a sense that his group and Pussy Riot shared certain problems - repression by the authorities, difficulty in gaining political influence-Alex still created distance between Pussy Riot and his own group. Thus Alex's analysis and critique of Pussy Riot simultaneously functioned as a legitimation of his own group's tactics and ideology.

As Alex himself noted, he was expressing a position shared by others in his leftist organisation. Members of the group had discussed the case extensively and circulated their analyses not only in conversation, but also in written form, as in this excerpt from his comrade Igor's essay in the samizdat feminist journal "No Means No!".

The persecution of anti-Putin "blasphemers" has caused a strong reaction in society. The growing movement of solidarity with the repressed underscores the rigidity and inflexibility of their pursuers among politicians and clergy. If the heiresses of "Voina," 11 Pussy Riot, didn't quite cause a war in society, then they certainly became symbols of the spirit of rebellion in recent times. [...]

For critique, the weakest point in their performance in the Cathedral is the fact that their political 'message' was not in fact addressed to the mass of common workers, and so in many ways it hasn't found a real response among them. Why the imprisonment of some 'hooligans' should bother them remains unclear to the majority, while it's easier to explain to many why a performance in a cathedral ought to anger them.

Like Alex's statement, Igor's essay commented on Pussy Riot's performance while at the same time highlighting his own political expertise and position. This brief response to the punk prayer asserted relationships among a host of objects within the political-moral field: Pussy Riot, the ruling elite, Alex's group, the working class. To be clear, this leftist response to the Pussy Riot provocation was not anti-feminist or anti-LGBT; Igor was in fact a prominent activist for LGBT rights and made a point of including gender analysis in his other critiques of Russian capitalism and state power. But by and large my interlocutors active in the anti-Putin opposition tended to interpret and respond to the Pussy Riot case in ways that focused on state repression, not quite claiming Pussy Riot as connected to feminist or LGBT rights messages. The effect of this interpretation was to reinforce values related to democracy, free expression, a fair justice system, and (among leftists) class struggle, rather than reinvigorating a specifically feminist and LGBT-focused message and movement.

\section{AMBIVALENCE AND DISAVOWAL: RUSSIAN FEMINISTS RESPOND}

Russian Orthodox responses to Pussy Riot placed them in the context of a struggle between provocative and threatening feminism and 'traditional values', resulting in a reinforcement of those values opposed to feminism and LGBT rights. Those who defended Pussy Riot within the liberal and left anti-Putin opposition connected the group to broader narratives of an oppressive political system, which reinforced neither feminism or an LGBT rights message, resulting in an asymmetry in responses to Pussy Riot's provocation.

This asymmetry continued with the ambivalence of feminist responses, which did not simply defend Pussy Riot as part of the feminist movement in a way that mirrored Russian Orthodox activists' opposition to Pussy Riot as part of the feminist threat to society. In their discussions of Pussy Riot, many feminist activists criticised the group as they defended other visions of what feminism represented and of what tactics were appropriate for feminist activism, asserting a certain distance between their vision of feminism and their understanding of Pussy Riot. Indeed, even the group's own closing statements at court, which cited a rich range of sources from Soviet dissidents to Dostoyevsky to the Bible, included almost no mention of feminism or women's rights themes (Alyokhina et al., 2012; see also Akulova, 2013), in curious contrast to the punk prayer itself, whose chorus was "Mother of God, become a feminist!"

The contest to define Pussy Riot's relationship to the rest of the feminist community was heated, similar to what Jessica Zychowicz (2011) found among Ukrainian feminist reactions to Femen. The reactions of some Russian feminists indicated that they experienced the punk prayer and its aftermath as provocations against two,

\footnotetext{
${ }^{11}$ Voina was a radical art collective active in Moscow and St. Petersburg during the 2000s and included Nadya Tolokonnikova
} among its members.

$10 / 14$

(C) 2018 by Author/s 
sometimes conflicting, values. On the one hand, they linked Pussy Riot's prosecution to their own experiences of repression and marginalisation by the Orthodox Church and Russian state. On the other hand, they often rejected claims that Pussy Riot represented Russian feminism, attempting rhetorically to shore up their own vision of the Russian feminist movement and its values and goals by distancing it from Pussy Riot's actions. At times, even the claim that Pussy Riot had something to do with feminism seemed almost as much of a provocation as their arrest. As Vera Akulova put it, "the perception of Pussy Riot among Russian feminists was extremely ambivalent" (2013: 282, see also Sperling, 2015).

Natasha Bitten, a journalist who ran an internet community for Russian feminists and had helped organise protests for abortion rights, expressed this ambivalence in writing about how the Russian and international media were responding to the Pussy Riot case. The Russian magazine Snob published an interview in which an expatriate Russian feminist seemed to claim that feminism in Russia had been almost dead before Pussy Riot appeared. Natasha responded with a defence of the Russian feminist movement that disavowed Pussy Riot as a feminist organisation.

Russian feminists were accused of being stupid, ignorant, uninformed [... In all this goes unmentioned the fact that Pussy Riot, and in particular, those arrested for the action in CCS, distanced themselves as much from the ideas of feminism as from Russian feminist organizations [...]. The group PR has in no way supported the struggle of Russian feminist groups against the anti-woman draft law of the Duma restricting the reproductive rights of Russian women. When the anti-abortion law was passed all the same, Pussy Riot announced that feminism in the Russian Federation doesn't exist, because the problem of abortion doesn't trouble anyone, didn't cause any mass protests, and wasn't publicized at all in mass media.

Unlike the Russian Orthodox women's responses, Natasha's statement attempted to separate Pussy Riot from the categories of feminism and Russian feminist organisations. She also compared the global attention Pussy Riot received to the difficulty other Russian women's groups had in getting notice for their struggles, for example when she had sought recognition from the UN Commission on the Status of Women of rights violations in Russia. For her, Pussy Riot's provocation was not that they attacked the Orthodox Church and not only that their punishment demonstrated a government edging into authoritarianism, but that their media success seemed to erase the rest of the Russian feminist community.

Similarly, Tatyana, a businesswoman and feminist, rejected the notion that Pussy Riot had anything to do with feminism when asked about the group during a press conference for an International Women's Day event in 2013, and even identified the group's provocation in terms not dissimilar from those of the Orthodox women activists described earlier.

Understand, feminists are often associated with Pussy Riot, with Femen. We have no connection with these movements, and in principle, in my view of Pussy Riot and Femen alike, they have nothing in common with feminism. [...] If you enter the space of an Orthodox cathedral, you should conduct yourself according to the rules that exist there, whether you're a person of faith or not.

Even members of Pussy Riot at times declined to link their actions with those of other feminist groups. Recall that the Russian Orthodox activist Anna equated Pussy Riot to the Ukrainian group Femen, asserting that they were both part of a broader global movement of feminists threatening traditional values. But in an interview after her release, Pussy Riot member Ekaterina Samutsevich rejected that clasp.

Kseniya Sobchak: And how do you relate to Femen? Many believe that is your Ukrainian analogue.

Ekaterina Samutsevich: No, I don't believe that is an analogue. They are entirely unlike us in form and even in their view of feminism. [...] Our character is not a girl who takes her clothes off because she wants to look pretty for men. Femen doesn't hide this and writes that 'men want to see women, and so we appear. Through an image that pleases men, we will advance feminism.' [...] We cover our faces. We have a rather androgynous image, a kind of being in a dress and colored tights. Something resembling a woman, but without a woman's face, without hair. An androgyne, resembling a hero from a cartoon, a superhero (Sobchak and Sokolova, 2012).

In contrast to the responses of many other Russian feminists, Samutsevich's response underscores elements of Pussy Riot's performance she connects to feminist goals: here, rejecting the notion that women must appeal to the male gaze. Samutsevich rejected the association that others had made between Pussy Riot and Femen. In doing so, she questioned the form of Femen's feminist activism—appealing to the male gaze—and thereby legitimated her own group's vision, an anonymous superhero whose gender is unclear. 
Not all feminist responses to Pussy Riot involved total rejection of the group; however, they tended not to defend the group as representatives of feminism, nor did their responses tend to energise values related to gender equality or other specifically feminist goals. Particularly as the members' detention, trial, and imprisonment proceeded, the three arrested Pussy Riot members were instead increasingly framed as "conscientious political prisoners" by many feminists, similar to other participants in the opposition. These responses suggested that for many Russian feminists, the fundamental provocation of the Pussy Riot case had to do with state repression, prompting them to assert and reinforce norms related to the criminal justice system, rather than those related to the position and treatment of women in society.

'Alla,' a college student who had become interested in feminism and LGBT rights through participation in protests, expressed this combination of sympathy and judgement in an interview after the trial had ended when I asked what she thought about Pussy Riot.

Alla: That's very complicated [...] On the one hand, without a doubt they suffered unjustly. They were imprisoned absolutely illegally. That entire suit, all those charges, it was some kind of absolutely scary circus. On the other hand, to be honest, what they did was objectionable to me. That action was simply terrible in my view. [...] I didn't go to a single action supporting them because I didn't think that what they did was acceptable.

In ambivalent responses like these, feminists tended to identify the core provocations of the case as Pussy Riot's transgression of norms of appropriate protest and the state's extreme and repressive response.

Even as activists like Alla and Natasha grew more sympathetic to the group's plight as their prosecution and imprisonment continued, their clasps continued to relate the Pussy Riot case primarily to that state repression, leaving aside the feminist and LGBT themes they might have raised.

For example, after meeting at a poetry reading marking the one-year anniversary of the punk prayer, Natasha and I walked back to the metro together, passing CCS on the way. Natasha pointed out the cathedral, recounting how she often walked by and overheard tour groups learning about the historical site. "Do you know what foreigners call it now?," she asked.

"No," I replied.

Smiling wryly, she answered, "The Pussy Riot cathedral." Despite all the efforts of the Church and state to repress and punish them, the group had nonetheless become embedded in the tourist landscape of Moscow. Even in this moment of sympathy, though, Natasha's comment emphasised Pussy Riot's impact on foreign tourists, not on Russian audiences.

The conflict around defining Pussy Riot's relationship to feminists and feminism shows how a provocation can gain wide notice and resonance as a result of its transgressive form, seeming to force people to interpret and respond to it, a potential boon to grassroots activists with relatively few resources to spread a message. Yet, as careful attention to the specific dynamics of provocation reveals, what message is spread and what values are normalised or reinforced is shaped by what people identify as the specific norms being transgressed. The fact that few of my interlocutors sympathetic to Pussy Riot, even self-identified feminists, associated the group with feminist or LGBT values meant that the latter themes were not being circulated strongly alongside positive messages about the group. In contrast, how Russian Orthodox interlocutors identified Pussy Riot's provocation and responded to it clearly connected the group to the feminist and LGBT rights movements. Where Orthodox responses to Pussy Riot's provocations reinforced anti-feminist and anti-LGBT rights values, connecting those values to Orthodoxy and the Russian state, Russian feminist reactions instead tended to distance Pussy Riot from feminism and even from Russia, instead emphasising a different set of norms related to state power and the court system. Together with the comments of leftist and liberal opposition activists that rarely raised feminism or LGBT rights at all, the net result was that the responses of those who supported Pussy Riot simply did not solidify and energise values related to feminism, women's rights, and LGBT rights in a way comparable to the revitalisation of anti-feminist, anti-LGBT values of Pussy Riot's Orthodox critics.

\section{FEMINIST PROVATION AND REACTIONARY RETRENCHMENT}

Borrowing the concept provokatsiya from some of my Russian interlocutors, I have argued that provocation is a key concept for understanding the dynamics of confrontational and transgressive protest. In particular, understanding how provocation operates makes clear why provocative actions often result in widespread circulation of a protest or performance: a provocation is experienced as a transgression of norms so extreme that one cannot help but respond. But while a provocation may invite mass circulation, there is no guarantee that the meanings intended by the provocateur will circulate along with it. Pussy Riot's iconic uniforms, the transgressive location and subject of their action, and the symbolic richness of their performance encouraged the series of clasps 
that made their performance circulate around Moscow, Russia, and the globe. But the fact that the performance of a feminist, pro-LGBT rights group was so widely circulated did not mean that feminism and LGBT rights themselves were revitalised in Russia. As I have argued, key differences in how Russian Orthodox activists, left and liberal participants in anti-Putin protests, and Russian feminist activists identified and responded to Pussy Riot's provocations resulted in asymmetries in which values and world views their responses reinvigorated.

The 'punk prayer' provided an opportunity for observers to examine and discuss the moral and political landscapes of contemporary Russia as they parsed the group's meaning. By defining Pussy Riot, they defined themselves. The form and content of their performance, as well as the nature of responses to the group, invited observers especially to consider questions of Church and state interaction, the state of feminism in Russia, and rights of free speech and religious observance. Pussy Riot became evidence of a shocking moral decline, of the failure of the opposition to reach the working class, of growing political repression under Putin's government, and of the marginalisation of feminism in Russia.

By being radically transgressive, a provocation has the capacity to spur people to reinterpret and realign themselves in moral and political fields. Yet the impossibility of controlling their responses means that the results of successful circulation are unpredictable. In the case of Pussy Riot's provocation, asymmetrical responses among Russian Orthodox activists, left/liberal opposition activists, and Russian feminists illustrate how an ostensibly feminist protest may run the risk of revitalising anti-feminist opponents without a concomitant strengthening of feminist values among supporters.

In a dark irony, the same qualities that helped the group's performance circulate—a combination of provocation and symbolic multivocality — almost certainly contributed to the state's arrest, prosecution, and imprisonment of Tolokonnikova, Alyokhina, and Samutsevich. As Igor wrote, the case may even have been useful for the authorities in a time of increasing political unrest:

It's impossible not to notice that the authorities were able to manipulate the religious and national sentiments of people, since this allows them to amalgamate social protest and decrease the threat of open class conflict. That's why, on the other hand, no matter how careful Pussy Riot were, the authorities could always represent this in a light beneficial to themselves, as they have done with all protests.

As the Pussy Riot cases shows, provocations have a remarkable generative power and can be tremendously productive in terms of social and moral revitalisation. But it is critical not to confuse generative capacity with a necessarily progressive, democratic, or feminist outcome. Furthermore, a close analysis of provocation reveals how the apparent cultural continuity of "traditional values" is in fact constructed moment to moment. Provocations that aim to shift an anti-feminist, anti-LGBT rights, or authoritarian status quo may in fact revitalise the very values they intend to confront.

\section{REFERENCES}

(2013). Soderzhanie khrama Khrista Spasitelia v 2013 godu oboidetsia biudzhetu Moskvy v $350 \mathrm{mln}$ rublei. Gazeta. Available at: https://www.gazeta.ru/business/news/2013/02/14/n_2754521.shtml (Accessed 10 June 2017).

Agaltsova, A. (2014). Collective Female Identities in Discussions about Pussy Riot's Performance. Religion \& Gender, 4(2), 184-201. https://doi.org/10.18352/rg.9904

Akulova, V. (2013). Pussy Riot: Gender and Class, in M. Dziewanska, E. Degot and I. Budraitskis (eds.), Post-PostSoviet? Art, Politics, and Society in Russia at the Turn of the Decade (pp. 279-287). Warsaw, Poland: Museum of Modern Art.

Alyokhina, M., Tolokonnikova, N. and Samutsevich, Y. (2012). Pussy Riot Closing Statements. Available at: https:// nplusonemag.com/online-only/online-only/pussy-riot-closing-statements/ (Accessed 10 June 2017).

Baer, H. (2016). Redoing Feminism: Digital Activism, Body Politics, and Neoliberalism. Feminist Media Studies, 16(1), 17-34. https://doi.org/10.1080/14680777.2015.1093070

Bernstein, A. (2013). An Inadvertent Sacrifice: Body Politics and Sovereign Power in the Pussy Riot Affair. Critical Inquiry, 40(1), 220-241. https:/ / doi.org/10.1086/673233

Channell, E. (2014). Is Sextremism the New Feminism? Perspectives from Pussy Riot and Femen. Nationalities Papers, 42(4), 611-614. https:// doi.org/10.1080/00905992.2014.917074

Das, V. (1996). Critical Events: An Anthropological Perspective on Contemporary India. New Delhi: Oxford University Press.

Gal, S. (2007). Circulation in the "new" economy: Clasps and copies. 106th Meeting of the American Anthropological Association. Washington, D.C.

Groeneveld, E. (2014). Are W All Pussy Riot? On Narratives of Feminist Return and the Limits of Transnational Solidarity. Feminist Theory, 16(3), 289-307. https://doi.org/10.1177/1464700115604134 
Hoffman, D. and Lubkemann, S. (2005). Introduction: West-African Warscapes: Warscape Ethnography in West Africa and the Anthropology of "Events." Anthropological Quarterly, 78(2), 315-327. https://doi.org/10.1353/anq.2005.0024

Johnson, J. E. (2014). Pussy Riot as a Feminist Project: Russia's Gendered Informal Politics. Nationalities Papers, 42(4), 583-590. https://doi.org/10.1080/00905992.2014.916667

Moore, S. F. (1987). Explaining the Present: Theoretical Dilemmas in Processual Ethnography. American Ethnologist, 14(4), 727-736. https:// doi.org/10.1525/ae.1987.14.4.02a00080

Navalny, A. (2012). Pro pussi rayots. Available at: http://navalny.livejournal.com/690551.html (Accessed 10 November 2017).

Oushakine, S. A. (2004). The Flexible and the Pliant: Disturbed Organisms of Soviet Modernity. Cultural Anthropology, 19(3), 392-428. https:// doi.org/10.1525/can.2004.19.3.392

Pussy Riot. (2012). Pank-Moleben "Bogoroditsa, Putina Progoni” v Khrame Khrista Spasitelya. Trans. Jessica Mason. Available at: http://pussy-riot.livejournal.com/12442.html (Accessed 10 November 2017).

Robbins, J. (2003). On the paradoxes of global Pentacostalism and the perils of continuity thinking. Religion, 33, 221-321. https://doi.org/10.1016/S0048-721X(03)00055-1

Rourke, B. and Wiget, A. (2016). Pussy Riot, Putin and the Politics of Embodiment. Cultural Studies. 30(2), 234260. https://doi.org/10.1080/09502386.2014.974644

Sahlins, M. (1985). Islands of History. Chicago, University of Chicago Press.

Schroeder, R. L. and Karpov, V. (2013). The Crimes and Punishments of the 'Enemies of the Church' and the Nature of Russia's Desecularising Regime. Religion, State \& Society, 41(3), 284-311. https:// doi.org/10.1080/09637494.2013.837705

Shevzov, V. (2014). Women on the Fault Lines of Faith: Pussy Riot and the Insider/Outsider Challenge to PostSoviet Orthodoxy. Religion \& Gender, 4(2), 121-144. https://doi.org/10.18352/rg.9398

Sobchak, K. and Sokolova, K. (2012). Ekaterina Samutsevich. Neraschekhlennaya. Snob. Available at: http://www.snob.ru/selected/entry/53946 (Accessed 10 June 2017).

Sperling, V. (2015). Sex, Politics, and Putin: Political Legitimacy in Russia. New York: Oxford University Press.

Sperling, V. (2014). Russian Feminist Perspectives on Pussy Riot. Nationalities Papers, 42(4), 591-603. https:// doi.org/10.1080/00905992.2014.924490

Temkina, A. and Zdravomyslova, E. (2012). "Pussy Riot" y drugie: Novoe staroe litso feminizma. International scientific conference of the Russian Association of Researchers of Women's History (RAIZhI), 4-7 October. Tver', Russian Federation: Tver' State University.

Tolstaya, K. (2014). Stained Glasses and Coloured Lenses: The Pussy Riot Case as a Critical Issue for Multidisciplinary Scholarly Investigations. Religion \& Gender, 4(2), 100-120. https://doi.org/10.18352/rg.9838

Wiedlack, K. and Neufeld, M. (2014). Lost in Translation? Pussy Riot Solidarity Activism and the Danger of Perpetuating North/Western Hegemonies. Religion \& Gender, 4(2), 145-165. https:/ /doi.org/10.18352/rg.9215

Yurchak, A. (2006). Everything Was Forever, Until It Was No More: The Last Soviet Generation. Princeton: Princeton University Press.

Zavisca, J. R. (2011). Explaining and Interpreting the End of Soviet Rule. Kritika: Explorations in Russian and Eurasian History, 12(4), 925-940. https://doi.org/10.1353/kri.2011.0056

Zychowicz, J. (2011). Two Bad Words: FEMEN \& Feminism in Independent Ukraine. Anthropology of East Europe Review, 29(2), 215-227.

Citation: Mason, J. (2018). Pussy Provocations: Feminist Protest and Anti-Feminist Resurgence in Russia. Feminist Encounters: A Journal of Critical Studies in Culture and Politics, 2(1), 05. https://doi.org/10.20897/femenc.201805

Copyright (C) 2018 by Author/s and Licensed by Lectito BV, Netherlands. This is an open access article distributed under the Creative Commons Attribution License which permits unrestricted use, distribution, and reproduction in any medium, provided the original work is properly cited. 